\title{
p53-Independent Cyclin G Expression in a Group of Mature Neurons and Its Enhanced Expression during Nerve Regeneration
}

\author{
Naonori Morita, Sumiko Kiryu, and Hiroshi Kiyama \\ Department of Neuroanatomy, Biomedical Research Center, Osaka University Medical School, Osaka 565, Japan
}

An increase in cyclin $G$ expression after nerve injury was demonstrated by differential display PCR, carried out to compare differences in expression of mRNAs between axotomized and normal hypoglossal motoneurons in the rat. The nerve injury dramatically upregulated the expression of cyclin G mRNA in the motoneurons during the early phase of the nerve regeneration process, suggesting an involvement of cyclin $G$ in the early stage of nerve regeneration. In brain, in situ hybridization studies also demonstrated cyclin $\mathrm{G}$ expression in a restricted group of matured neurons, particularly in the telencephalon and the thalamus. This constitutive expression in mature neurons suggests that cyclin G may have a function different from other members of the cyclin group. In addition, although cyclin $\mathrm{G}$ has been shown to be a transcription target of $p 53$, the upregulation of cyclin $\mathrm{G}$ in injured motoneurons, as well as the expression in the adult rat brain, was not affected in the p53-deficient mouse. These data suggest that the expression of cyclin G, at least in the nervous system, is not regulated by p53 predominantly, and that there may be alternative regulatory factors or pathways for cyclin $\mathrm{G}$ expression.

Key words: tumor suppressor; cyclin G; nerve injury; differential display; PCR; hypoglossal nerve
When peripheral nerves are injured, the neurons start to produce molecules necessary for survival from the cell's death, for activation of surrounding glial cells and for rearrangement in intracellular signaling (Ludwin, 1984; Streit et al., 1988; Hatten et al., 1991; Yoneda et al., 1992; Kiryu et al., 1995a,b). All of these events must be well organized to ensure the success of nerve regeneration. Although various molecules are reported to be expressed after nerve injury, the precise mechanisms underlying the nerve regeneration process are unknown. To gain insight into the molecular mechanism underlying peripheral nerve regeneration, we have attempted to identify molecules involved in the process by using a technique termed differential display PCR (DD-PCR) (Liang et al., 1992; Kiryu et al., 1995b). The method is based on directly comparing the mRNAs expressed in two or more cell populations, separating their reverse transcription PCR products and comparing band patterns. We have used this method previously to identify a novel gene not previously implicated in peripheral nerve regeneration (Kiryu et al., 1995b). Using this technique, we demonstrate that cyclin $\mathrm{G}$, which belongs to cell cycle-related gene family, is dramatically upregulated during the early phase of the nerve regeneration process. Cyclin $G$ was initially isolated from a rat fibroblast cDNA library by crosshybridization with a mixture of c-src family kinase domains as a probe (Tamura et al., 1993). Cyclin G is currently highlighted as a transcription target of the p53 tumor suppressor protein (Okamoto and Beach, 1994); indeed, its gene contains two distinct p53 high-affinity binding sites upstream to its transcriptional start site

\footnotetext{
Received May 6, 1996; revised July 8, 1996; accepted July 10, 1996.
}

This study was supported in part by the Japan Society for the Promotion of Science and Grants-in-Aid for scientific research from the Ministry of Education, Science, and Culture of Japan. We are grateful to Dr. M. Tohyama for encouragement, and Drs. S. J. Augood, P. C. Emson, H. Ino, and H. Nojima for critical comments and English correction.

Correspondence should be addressed to Dr. Hiroshi Kiyama, Department of Neuroanatomy, Osaka University Medical School, 2-2 Yamadaoka, Suita, Osaka 565, Japan.

Copyright (C) 1996 Society for Neuroscience $0270-6474 / 96 / 165961-06 \$ 05.00 / 0$ and in the first intron (Zauberman et al., 1995). In fact, mouse embryonic fibroblasts from p53-deficient mouse expressed cyclin $\mathrm{G}$ at a level more than 10 -fold lower than that from a wild-type mouse (Okamoto and Beach, 1994). These findings strongly suggest that cyclin $\mathrm{G}$ is a target of p53 and may have some function in the biological effects of a tumor suppressor (Okamoto and Beach, 1994). Therefore, we also examined the involvement of p53 in the expression of cyclin $G$ both in normal brain and in injured motoneurons in p53-deficient mice.

\section{MATERIALS AND METHODS}

Animals. Seventy male Wistar rats weighing $\sim 100$ gm were anesthetized with pentobarbital $(45 \mathrm{mg} / \mathrm{kg})$ and positioned supine; the right hypoglossal nerve of each was then cut with scissors. The operated and normal sides of hypoglossal nuclei were dissected $7 \mathrm{~d}$ after the surgery, and 70 hypoglossal nuclei each (operated and normal) were collected and frozen in liquid nitrogen. For in situ hybridization, rats were killed 1, 3, 7, 14, 21, 28 , and $35 \mathrm{~d}$ after the operation ( 5 rats each point). Ten male p $53(-/-)$ and five wild-type mice (obtained from Oriental Yeast, Tokyo, Japan) (Tsukada et al., 1993) weighing $\sim 20$ gm were anesthetized with pentobarbital. The unilateral hypoglossal nerve was transected, and the animals were killed $7 \mathrm{~d}$ after the surgery.

$D D-P C R$. DD-PCR was carried out as described previously (Kiryu et al., 1995b). Total RNAs were obtained from operated and normal hypoglossal nuclei $7 \mathrm{~d}$ after surgery. Each $0.2 \mu \mathrm{g}$ of total RNAs was converted to cDNA with superscript reverse transcriptase (Life Technologies) and nucleotide oligo-dT ${ }_{18}$. Subsequently, one-tenth volume of the cDNA was amplified by PCR in the presence of $\alpha-\left[{ }^{35} \mathrm{~S}\right] \mathrm{dATP}$ using a single arbitrary primer, 5'-GTGAAGCACTACAAGATCCGG-3'. The cycling parameters are as follows: denaturation at $94^{\circ} \mathrm{C}$ for 5 min; 40 cycles with denaturation at $94^{\circ} \mathrm{C}$ for $30 \mathrm{sec}$; annealing at $42^{\circ} \mathrm{C}$ for $1 \mathrm{~min}$ and extension at $72^{\circ} \mathrm{C}$ for $1.5 \mathrm{~min}$; and an additional extention period at $72^{\circ} \mathrm{C}$ for $5 \mathrm{~min}$. Radiolabeled PCR products were analyzed by electrophoresis on a $5 \%$ sequencing gel and visualized by autoradiography. Differentially upregulated bands were recovered from dried denaturing polyacrylamide gels and reamplified in a 40-cycle PCR using corresponding primers. Reamplified cDNA products were cloned into TA vectors (Invitrogen, San Diego, CA).

PCR cloning of mouse cyclin $G c D N A$. For in situ hybridization histochemistry with p53-deficient mice, a PCR fragment of mouse cyclin G (368-1092) (Okamoto and Beach, 1994) was amplified using two primers, 5'-ACTGCAAGATTACGGGACTTTGAA-3' and 5'-CGTTGGGAGGTG- 
AGTTATTCTATA-3', from the mouse total brain cDNA. The cycling parameters are as follows: denaturation at $94^{\circ} \mathrm{C}$ for $5 \mathrm{~min} ; 40$ cycles with denaturation at $94^{\circ} \mathrm{C}$ for $30 \mathrm{sec}$; annealing at $60^{\circ} \mathrm{C}$ for $30 \mathrm{sec}$ and extension at $72^{\circ} \mathrm{C}$ for $1.5 \mathrm{~min}$; and an additional extention period at $72^{\circ} \mathrm{C}$ for $5 \mathrm{~min}$. The PCR product was cloned into pGEM-T vector (Promega, Madison, WI) and sequenced for confirmation.

Genotype analysis by PCR. Genomic DNAs were extracted from the liver of p53 (-/-) mice and wild-type CBA mice by the rapid preparation method (Davis et al., 1994). The genotype of mice was checked by PCR analysis according to Tsukada et al. (1993).

In situ hybridization. Animals were decapitated and the brains were quickly removed and frozen in powdered dry ice. Sections $20 \mu \mathrm{m}$ thick were cut on a cryostat, thaw-mounted onto 3-aminopropyltriethoxysilanecoated slides, and stored at $-80^{\circ} \mathrm{C}$ until used. ${ }^{35} \mathrm{~S}$-labeled RNA probes were prepared by in vitro transcription of the rat cyclin G cDNA (14-233) (Tamura et al., 1993) in pCR ${ }^{\mathrm{TM}} \mathrm{II}$, mouse cyclin G cDNA (368-1092) in pGEM-T vector (Okamoto and Beach, 1994), and cyclin D1 cDNA in pGEM-T (453-1013) vector (Bianchi et al., 1994) by using SP6 or T7 RNA polymerase and $\alpha$ - $\left[{ }^{35}\right.$ S] uridine triphosphate (Dupont NEN, Natick, MA). The in situ hybridization procedure was performed as described elsewhere (Kiryu et al., 1995b). For GAP-43 mRNA detection, an in situ hybridization using alkaline phosphatase-labeled oligonucleotide probe was performed. The in situ hybridization histochemistry method was basically performed as described elsewhere (Kiyama et al., 1990). The sequence of the probe was complementary to bases 136-174 of the rat GAP-43 cDNA (Yao et al., 1995b).

Relative quantification of $m R N A$. The grain intensity on the $\mathrm{x}$-ray film was measured. The relative area occupied by autoradiographic grains in the hypoglossal nuclei was measured bilaterally on the x-ray film using a computerized image analysis system (MCID, Imaging Research, St. Catharine's, Ontario, Canada). In the same sections, we calculated the difference in the optical density between the right (ipsilateral side) and the left (contralateral side) hypoglossal nuclei. For statistical analysis, at least eight sections from five rats were studied. Significant differences were determined using Student's $t$ test.

Northern hybridization. ApaI and SacI-digested rat cyclin G cDNA fragment, which was obtained by means of differential display, was labeled using a Multiprime DNA labeling system (Amersham, Buckinghamshire, England) and $\left[{ }^{32} \mathrm{P}\right]$ deoxycytosine triphosphate CTP (Dupont NEN) and used as a probe on Northern hybridization. Total RNA (20 $\mu \mathrm{g})$ from the total brain of p53 (-/-) mice and wild-type mice were electrophoresed on $1 \%$ agarose/formaldehyde gels and transferred to nitrocellulose filters (Amersham). The blots were hybridized with the labeled cyclin $\mathrm{G}$ cDNA probe in hybridization buffer $(50 \%$ deionized formamide, $5 \times$ saline sodium phosphate EDTA (SSPE), $5 \times$ Denhardt's solution, and $100 \mu \mathrm{g} / \mathrm{ml}$ salmon sperm DNA) overnight at $43^{\circ} \mathrm{C}$. Filters were then washed at $65^{\circ} \mathrm{C}$ in $2 \times \mathrm{SSPE} / 0.5 \% \mathrm{SDS}$ for $30 \mathrm{~min}$, and $0.2 \times \mathrm{SSPE} / 0.5 \%$ SDS for $30 \mathrm{~min}$, and exposed to $\mathrm{x}$-ray film at $-70^{\circ} \mathrm{C}$ with intensifying screens for $1 \mathrm{~d}$. After removing the hybridization probe from the filters by boiling in $0.5 \%$ SDS for $10 \mathrm{~min}$, blots were rehybridized with a labeled glyceraldehyde-phosphate dehydrogenase (GAPDH) cDNA to check that equal amounts of total RNA were loaded and transferred to the filters.

\section{RESULTS}

\section{Cloning of cyclin G by DD-PCR}

mRNA expression $7 \mathrm{~d}$ after hypoglossal nerve cut was analyzed using DD-PCR. We performed PCR amplifications using single arbitrary primer. The pattern of amplified cDNA fragments is indicated in Figure $1 A$. A cDNA fragment (Fig. $1 A$, arrowhead) was amplified to a greater degree on the operated side. This band was excised and used for further analysis. To eliminate falsepositive fragments, the upregulation of the mRNA expression was examined on tissue sections by in situ hybridization (in situ display). The cDNA fragment recovered from the differential display was reamplified using the same primer and used as a probe for in situ hybridization. This histological survey revealed a significant increase in mRNA expression in the injured hypoglossal nucleus (Fig. 1B). Searching the nucleotide data base, DDBJ, revealed that this clone corresponds to bases 3-233 of rat cyclin $\mathrm{G}$ se-

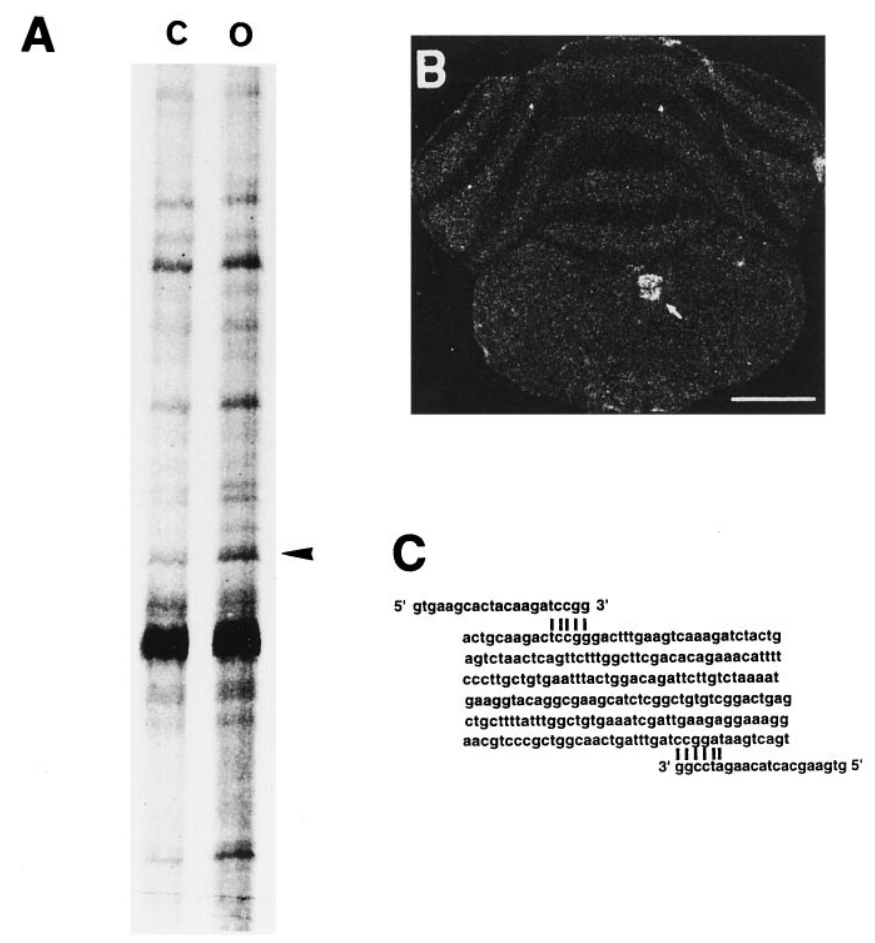

Figure 1. Results derived from DD-PCR. $A$ shows autoradiography of amplified ${ }^{35}$ S-labeled PCR products (after electrophoresis in $5 \%$ polyacrylamide gel) using a single arbitrary primer (see $C$ ). The left lane shows PCR products derived from normal hypoglossal nucleus $(C)$, and the right is from operated side $(O)$. Arrowhead indicates a differentially expressed band that is located at $\sim 200 \mathrm{bp}$ in size. $B$, Histological display by in situ hybridization using the cDNA fragment derived in $A$ (arrowhead). The section was obtained from an animal whose unilateral hypoglossal nerve was axotomized $7 \mathrm{~d}$ before (right side is the operated side). A hybridization signal is observed only in the injured side of the hypoglossal nucleus (arrow). Scale bar, $2 \mathrm{~mm}$. $C$, Sequence of the derived band that corresponds to rat cyclin $\mathrm{G}$ and the primer annealing. Five to six bases of the $3^{\prime}$ end of the primer are annealed for the detection of this band.

quence (Tamura et al., 1993). Only 5-6 bases of the 3' end of the primer were found to be annealed (Fig. 1C).

\section{Expression profile of cyclin G during nerve regeneration}

We carried out in situ hybridization to evaluate changes in rat cyclin $\mathrm{G}$ mRNA expression over time during the nerve regeneration (Figs. 2, 3). A significant increase in rat cyclin $G$ hybridization signal was observed in the ipsilateral hypoglossal nucleus $1 \mathrm{~d}$ after the nerve cut. Moreover, the intensity of the hybrydization signal markedly increased to peak levels during the next $3 \mathrm{~d}$ and decreased gradually to control levels over the next 3 weeks (Figs. 2, 3). Cyclin D1 mRNA expression was not observed both in the operated and control sides of hypoglossal nuclei throughout the examined period.

\section{Constitutive expression of cyclin $\mathrm{G}$ in a group of neurons}

In addition to the appearance of cyclin $\mathrm{G}$ mRNA in the injured motoneuron, cyclin $\mathrm{G}$ mRNA expression also was observed in neurons located in some specific brain regions (Fig. 4). An intense cyclin G mRNA signal was observed predominantly in the telencephalon and the thalamus. Most telencephalic regions, including the olfactory bulb, the anterior olfactory nuclei, and the hippocampus, expressed an intense hybridization signal. In the hip- 

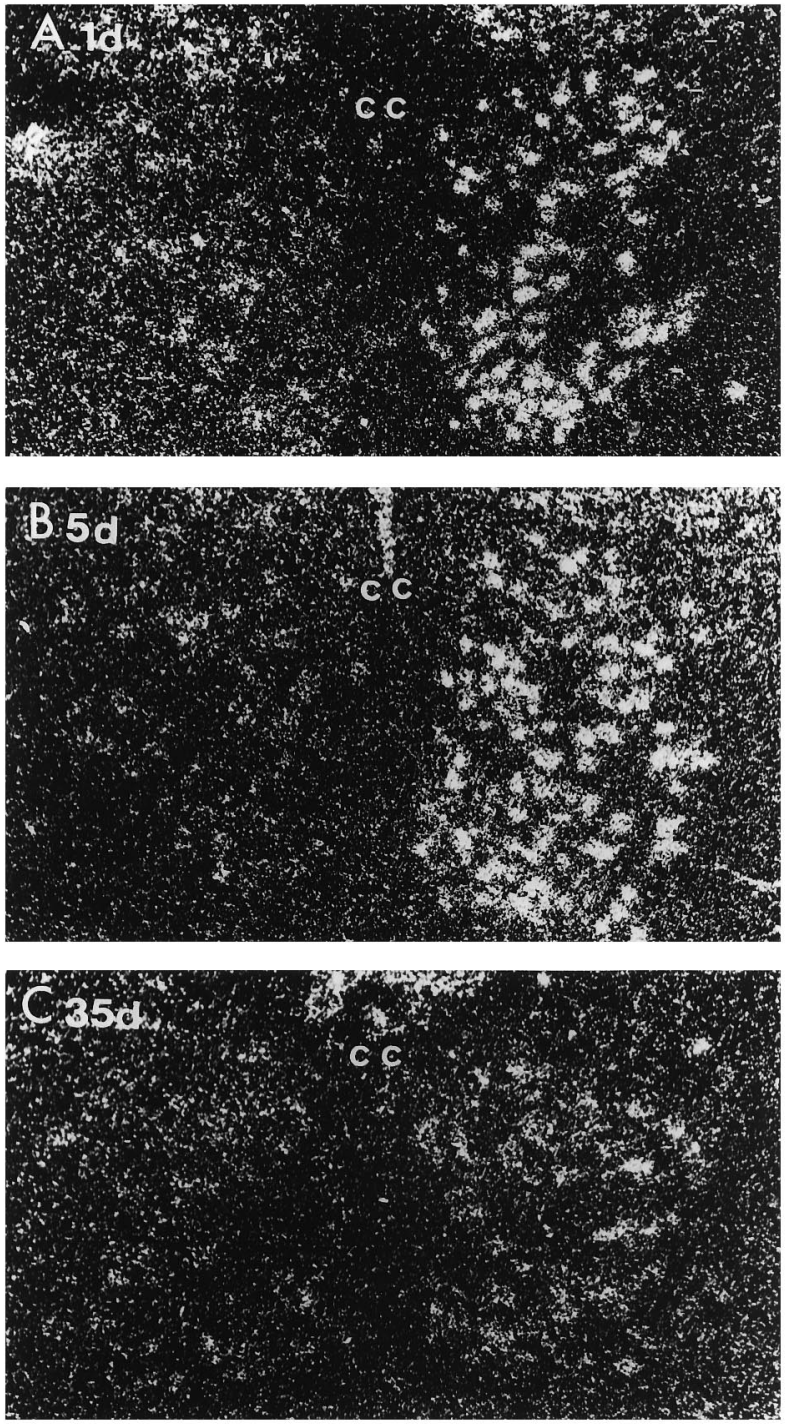

Figure 2. Expression of the rat cyclin G mRNA in the hypoglossal nucleus $1(A), 5(B)$, and $35(C) \mathrm{d}$ after unilateral hypoglossal nerve transection (right side). $c c$, Central canal. Scale bar, $100 \mu \mathrm{m}$.

pocampus, the mRNA level appeared slightly stronger in CA2 than in other CA regions (Fig. 4C). One unexpected finding was that expression of cyclin $\mathrm{G}$ mRNA was found throughout the thalamus (Fig. 4C,D). Most of the neurons belonging to the thalamus, from the anterior thalamic nuclei to the medial geniculate body caudally, showed a moderate level of hybridization signal. In addition, a weak hybridization signal was observed in the superior colliculus, inferior colliculus, and locus coeruleus. In the cerebellum, a moderate-to-weak hybridization signal was observed in the granule cell layer and the Purkinje cell layer.

\section{Cyclin G expression is enhanced in the injured motoneurons of p53-deficient mice}

Because it has been demonstrated that cyclin $G$ is a transcriptional target of p53, we examined the expression of cyclin $G$ in p53-deficient mice. Genomic DNA of wild-type and p53-deficient mice was checked by PCR before nerve injury (Fig. 5). Upregulation of cyclin $\mathrm{G}$ mRNA expression also was observed in the denervated hypoglossal nucleus of p53-deficient mice, as well as that of GAP-43 mRNA expression, which could be a marker for

\section{Cyclin G mRNA expression}

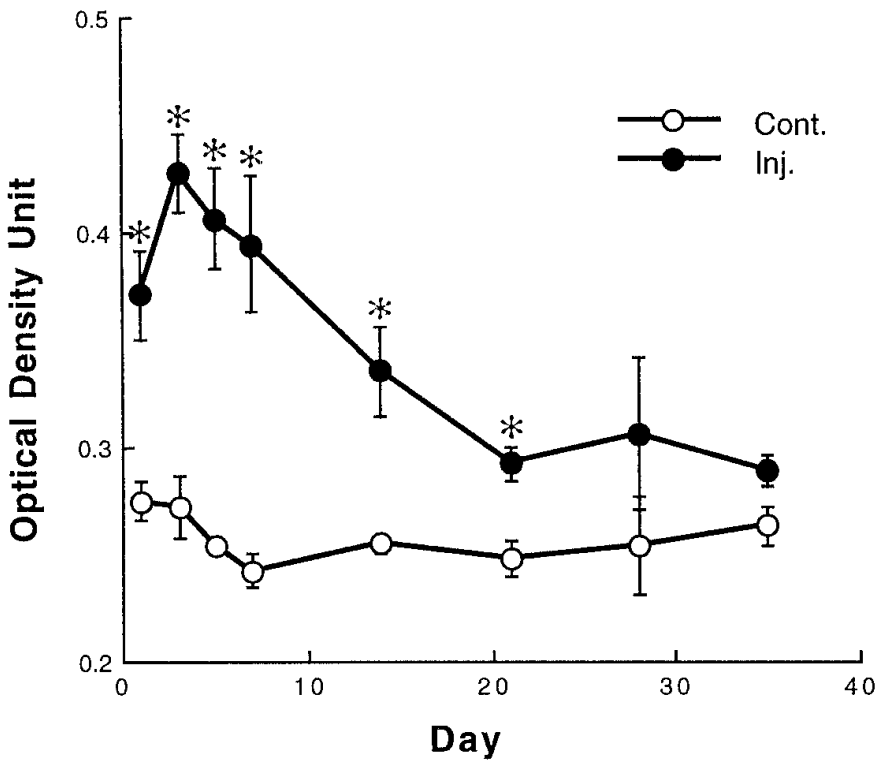

Figure 3. Semiquantification of cyclin G mRNA expression profile in both injured (filled circles) and control (open circles) sides. Each point shows the average intensity of the positive signal and SD. Asterisks denote statistically significant differences (Student's $t$ test) from control. ${ }^{*} p<0.01$.

nerve regeneration (Kobayashi et al., 1994) (Fig. 6). In addition, the distribution of cyclin G mRNA expression in wild-type and p53-deficient mice was identical (Fig. 7). This localization of cyclin $\mathrm{G}$ mRNA expression appeared almost identical between rat and mouse. Because cyclin G mRNA expression was unexpectedly observed in the p53-deficient mice, we further examined the expression by Northern blot analysis. Cyclin G mRNA levels in p53 deficient mice appeared slightly weaker than that of wild-type mice (Fig. 7C). However, at the cellular level, the in situ mRNA signal intensity observed in both p53-deficient and wild-type brain section was comparable.

\section{DISCUSSION}

In the present study, DD-PCR was used to identify cyclin G as a molecule associated with peripheral nerve regeneration. The present study, together with our previous study (Kiryu et al., 1995b), has demonstrated the value of this method in the identification of molecules that are involved in the peripheral nerve regeneration process. Cyclin $\mathrm{G}$ is expressed in injured motoneurons particularly during the early phase of the regeneration process. In our hypoglossal nerve transection model, complete nerve regeneration, target reinnervation, takes more than 2 months (Kobayashi et al., 1994). Throughout this regenerative process, GAP-43 mRNA expression can be observed, and it is a good marker for the extent of regeneration (Kobayashi et al., 1994). A substantial increase in cyclin G mRNA expression is observed within $24 \mathrm{hr}$ after the surgery, and this upregulation persists during the first 2 weeks, revealing that cyclin $G$ expression is therefore restricted to the early phase of regeneration. Such early-phase expression seems to be common among molecules that belong to the immediate early gene family (Haas et al., 1993; Herdegen and Zimmerman, 1994); growth factor and cytokine receptors (p75NGFR, TrkB) (Saika et al., 1991; Frisen et al., 1992); gp130 (Yao et al., 1995a) and their signaling molecules 

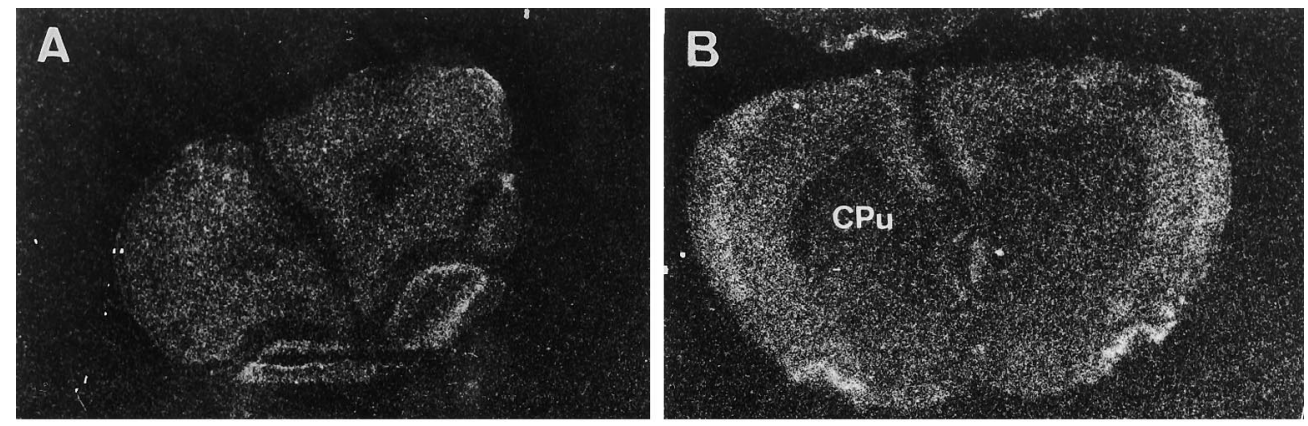

Figure 4. Expression of the rat cyclin $\mathrm{G}$ mRNA in rat brain. $A-D$, Expression of the rat cyclin $\mathrm{G}$ mRNA in neurons of frontal cortex and olfactory nuclei $(A)$, pyriform cortex $(B)$, cerebral cortex, hippocampus, and thalamus $(C)$, caudal part of cerebral cortex, the medial geniculate body $(M G)$, and superior colliculus $(C S)(D)$. Note that the hybridization signal is intense in telencephalon $(A-D)$ and thalamus $(C)$, but low in caudate putamen $(C P u)$, hypothalamus $(C)$, and midbrain $(D)$. Scale bar, $1 \mathrm{~mm}$.
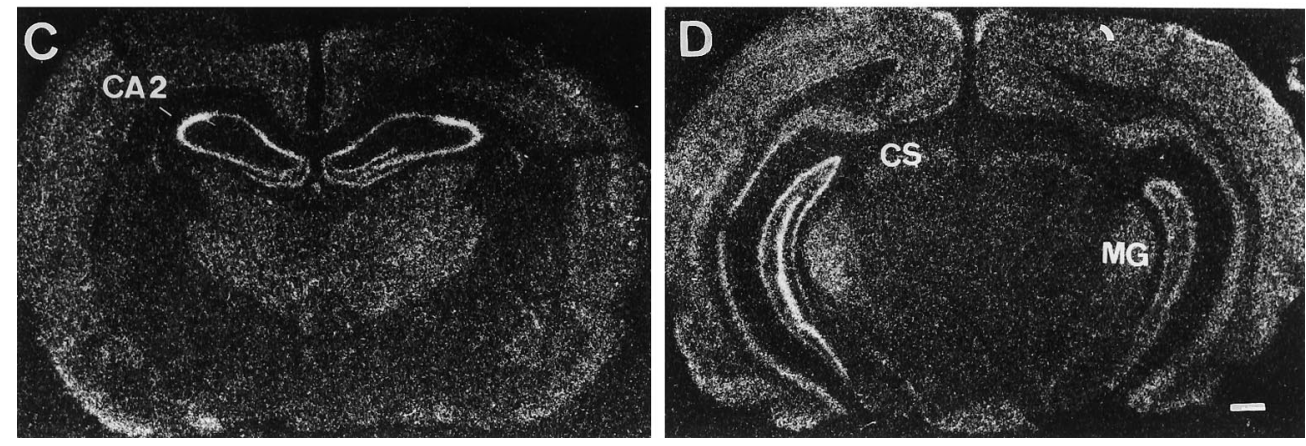

(JAK) (Yao et al., 1995a); and molecules related to survival from injury, such as neuronal glutamate transporter (Kiryu et al., 1995b). Cyclin G was originally identified by cross-hybridization with a c-src kinase domain, and this cyclin has a possible tyrosine phosphorylation site in addition to a cyclin box (Tamura et al., 1993). The existence of a possible phosphorylation site is not common in other cyclins. Thus, cyclin $\mathrm{G}$ may have two distinct profiles, both as a cyclin and as a intracellular signaling molecule (Tamura et al., 1993). Although the functional significance of cyclin $\mathrm{G}$ is still unknown, this molecule seems to play some role in the early stage of the regeneration process.

Another finding in brain is that a group of mature neurons constitutively expresses cyclin $\mathrm{G}$ despite the inability of the neurons to proliferate. In particular, neurons located in the telen-
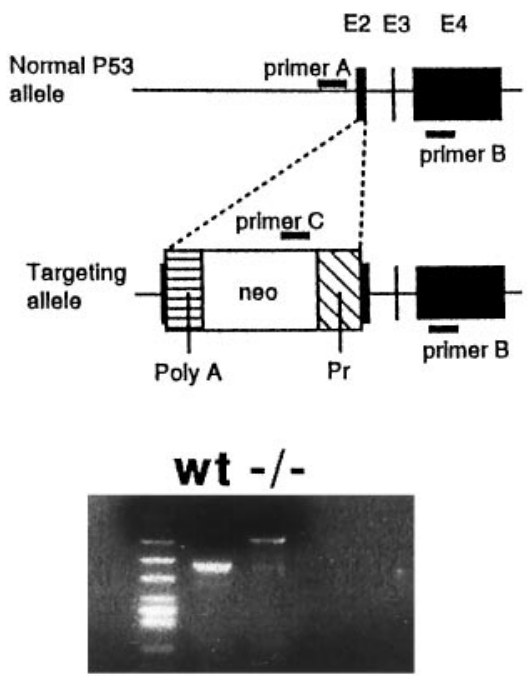

Figure 5. Genotype analysis of p53-deficient mouse used in this experiment. Three primers $(A-C)$ were designed for the detection of genotype by PCR. In the normal allele, a $500 \mathrm{bp}$ of amplifications between primer $\mathrm{A}$ and $\mathrm{B}$ was observed, and in the targeting allele, an $800 \mathrm{bp}$ of amplifications between primer $\mathrm{A}$ and $\mathrm{C}$ was observed. cephalon and the thalamus expressed substantial amounts of cyclin $G$ mRNA even in the adult rat. Cyclin D1 is another member that is also expressed in mature neurons, and the localization of cyclin $\mathrm{G}$ in the brain is distinct from that of cyclin D1 (Tamaru et al., 1993). This restricted localization of cyclin G in mature neurons suggests another function of cyclin $\mathrm{G}$ in addition to its function in the cell cycle. Recently, cyclin $\mathrm{H}$ and associated cyclin-dependent kinase have been shown to be involved in the gene transcription machinery TFIIH complex (Fisher and Morgan, 1994; Makera et al., 1994; Roy et al., 1994; Serizawa et al., 1995; Shiekhattar et al., 1995). This extends the idea that some types of cyclin and associated cdc or cdk could be components of transcription factors (Maldonado and Reinberg, 1995). Although the cyclin G-associated kinase has not yet been identified, the complex of this kinase and cyclin $\mathrm{G}$ may be involved in a transcription factor complex that may be important for gene expres-
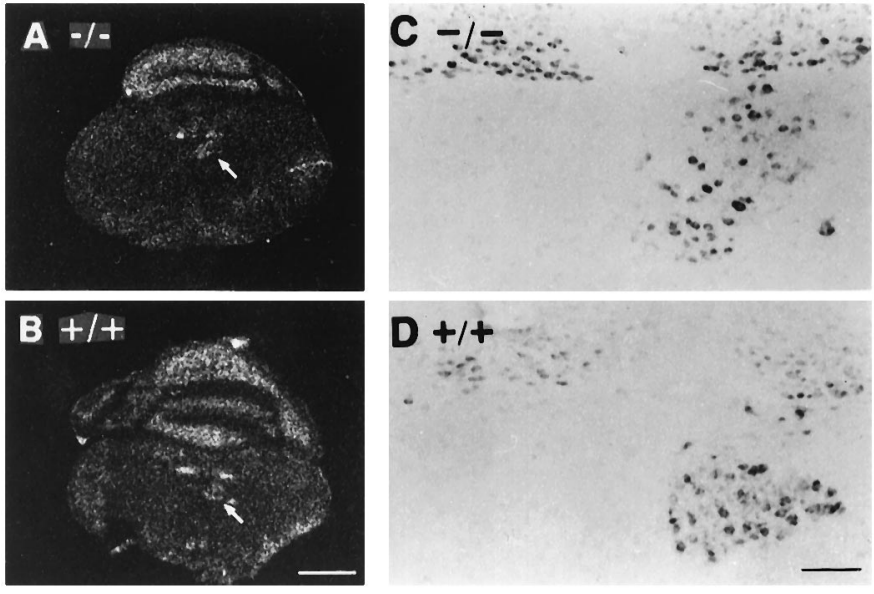

Figure 6. Cyclin $\mathrm{G}(A, B)$ and GAP-43 $(C, D)$ mRNA expression in injured hypoglossal nuclei of p53-deficient $(A, C ;-/-)$ and wild-type $(B$, $D ;+/+)$ mice. Both cyclin G and GAP-43 mRNA expressions are seen in control and injured hypoglossal nuclei with a similar intensity (arrows). Scale bars: $1 \mathrm{~mm}$ in $A$ and $B ; 100 \mu \mathrm{m}$ in $C$ and $D$. 

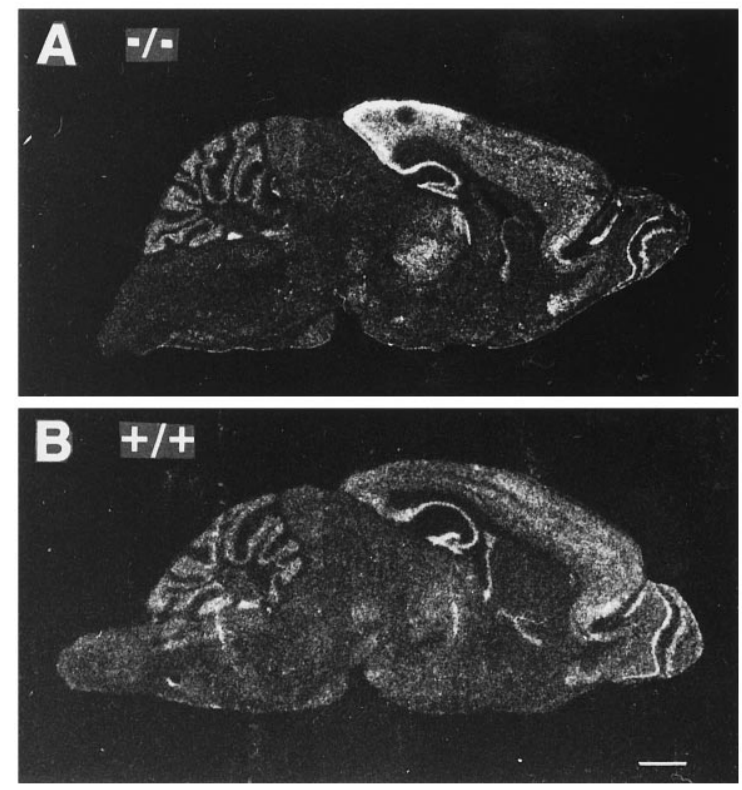

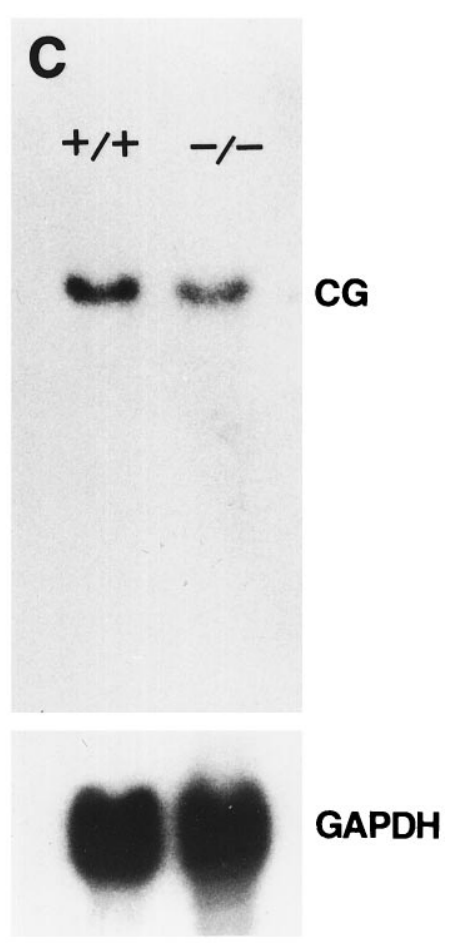

Figure 7. In situ hybridization $(A, B)$ and Northern analysis $(C)$ of cyclin $\mathrm{G}$ expression in p53-deficient and wild-type mice. Similar expression profiles are seen in p53-deficient $(A)$ and wild-type $(B)$ brain. Northern analysis demonstrates a slight decrease of cyclin $\mathrm{G}$ mRNA expression in p53-deficient brain $(-/-)$. GAPDH is used for the control. Scale bar, $1 \mathrm{~mm}$. sion in the telencephalon and thalamus. In addition, it is known that TFIIH participates in nucleotide excision repair (Roy et al., 1994). This suggests that the cyclin containing TFII might have a specific function. Therefore, it is likely that cyclin $G$ and its corresponding cdk complex may be involved in a specific transcription factor complex, and this complex may be necessary for the gene expression required for peripheral nerve regeneration.

Recently, cyclin $\mathrm{G}$ has been identified as a gene transcription target for p53 (Okamoto and Beach, 1994; Zauberman et al., 1995). Expression of cyclin G mRNA in embryonic fibroblasts from p53-deficient mice was shown to be much less than that derived from wild-type mice (Okamoto and Beach, 1994). Thus, we expected that the upregulation of cyclin $G$ mRNA expression after nerve injury might also be regulated by $\mathrm{p} 53$ in these animals. Therefore, we examined cyclin G mRNA expression after the hypoglossal nerve axotomy in the p53-deficient mouse. Strikingly, the p53 deficiency did not affect cyclin $\mathrm{G}$ expression levels in the injured motoneurons. In addition, in situ hybridization demonstrated that the cyclin $\mathrm{G}$ expression in the brain appeared comparable to the wild types. Another nerve regeneration marker, GAP-43 expression, was not altered between wild-type and p53deficient mice, suggesting nerve regeneration might not be affected by p53 deficiency. Although we could not find any difference in expression of cyclin $\mathrm{G}$ between the wild-type and $\mathrm{p} 53$ deficient mice, Northern analysis showed a slight decrease in cyclin G mRNA expression in p53-deficient mice. Nonetheless, these data suggest, at least in the nervous system, that p53 does not regulate cyclin $\mathrm{G}$ expression predominantly (even though the cyclin $\mathrm{G}$ gene has p53 binding sites) (Zauberman et al., 1995) and that alternative regulatory pathways may exist.

\section{REFERENCES}

Bianchi S, Fabiani S, Muratori M, Arnold A, Sakaguchi K, Miki T, Brandi ML (1994) Calcium modulates the cyclin D1 expression in a rat parathyroid cell line. Biochem Biophys Res Commun 204:691-700.

Davis LG, Kuehl WM, Battey JF (1994) Basic methods in molecular biology, 2nd Ed, pp 307-309. Norwalk, CT: Appleton \& Lange.
Fisher RP, Morgan DO (1994) A novel cyclin associates with MO15/ CDK7 to form the CDK-activating kinase. Cell 78:713-724.

Frisen J, Verge VMK, Cullheim S, Persson H, Fried K, Middlemas DS, Hunter T, Hokfelt T, Risling M (1992) Increased levels of trkB mRNA and trkB protein-like immunoreactivity in the injured rat and cat spinal cord. Proc Natl Acad Sci USA 89:11282-11286.

Haas CA, Donath C, Kreutzberg GW (1993) Differential expression of immediate early genes after transection of the facial nerve. Neuroscience 53:91-99.

Hatten ME, Liem RKH, Shelanski ML, Mason CA (1991) Astroglia in CNS injury. Glia 4:233-243.

Herdegen T, Zimmermann M (1994) Expression of c-Jun and JunD transcription factors represent specific changes in neuronal gene expression following axotomy. Prog Brain Res 103:153-171.

Kiryu S, Morita N, Ohno K, Maeno H, Kiyama H (1995a) Regulation of mRNA expression involved in Ras and PKA signal pathways during rat hypoglossal nerve regeneration. Mol Brain Res 29:147-156.

Kiryu S, Yao GL, Morita N, Kato H, Kiyama H (1995b) Nerve injury enhances rat neuronal glutamate transporter expression: identification by differential display PCR. J Neurosci 15:7872-7878.

Kiyama H, Emson PC, Tohyama M (1990) Recent progress in the use of the technique of nonradioactive in situ hybridization histochemistry; new tool for molecular neurobiology. Neurosci Res 9:1-21.

Kobayashi N, Kiyama H, Tohyama M (1994) GAP-43 (B50/F1) gene regulation by axonal injury of the hypoglossal nerve in the adult rat. Mol Brain Res 21:9-18.

Liang P, Pardee AB (1992) Differential display of eukaryotic messenger RNA by means of polymerase chain reaction. Science 257:967-971.

Ludwin SK (1984) Proliferation of mature oligodendrocytes after trauma to the central nervous system. Nature 308:274-275.

Makera TP, Tassan J-P, Nigg EA, Frutiger S, Hughes GJ, Weinberg RA (1994) A cyclin associated with the CDK-activating kinase MO15. Nature 371:254-257.

Maldonado E, Reinberg D (1995) News on initiation and elongation of transcription by RNA polymerase II. Curr Opin Cell Biol 7:352-361.

Okamoto K, Beach D (1994) Cyclin G is a transcriptional target of the p53 tumor suppressor protein. EMBO J 13:4816-4822.

Roy R, Adamczewski JP, Seroz T, Vermeulen W, Tassan J-P, Schaeffer L, Nigg EA, Hoeijmakers JHJ, Egly J-M (1994) The MO15 cell cycle kinase is associated with the TFIIH transcription-DNA repair factor. Cell 79:1093-1101.

Saika T, Senba E, Noguchi K, Sato M, Yoshida S, Kubo T, Matsunaga T, Tohyama M (1991) Effects of nerve crush and transection on mRNA 
levels for nerve growth factor receptor in the rat facial motoneurons. Mol Brain Res 9:157-160.

Serizawa H, Makela TP, Conaway JW, Conaway RC, Weinberg RA, Young RA (1995) Association of cdk-activating kinase subunits with transcription factor TFIIH. Nature 374:280-282.

Shiekhattar R, Mermelstein F, Fisher RP, Drapkin R, Dynlacht B, Wessling HC, Morgan DO, Reinberg D (1995) Cdk-activating kinase complex is a component of human transcription factor TFIIH. Nature 374:283-287.

Streit WJ, Graeber MB, Kreutzberg GW (1988) Functional plasticity of microglia: a review. Glia 1:301-307.

Tamura K, Kanaoka Y, Jinno S, Nagata A, Ogiso Y, Shimizu K, Hayakawa T, Nojima H, Okayama H (1993) Cyclin G: a new mammalian cyclin with homology to fission yeast Cig1. Oncogene 8:2113-2118.

Tamaru T, Trigum SK, Okada M, Nakagawa H (1993) Identification of cells expressing a D type G1 cyclin in matured brain: implication for its role in neuronal function. Neurosci Lett 153:169-172.
Tsukada T, Tomooka Y, Takai S, Ueda Y, Nishikawa S-I, Yagi T, Tokunaga T, Takeda N, Suda Y, Abe S, Matsuo I, Ikawa Y, Aizawa S (1993) Enhanced proliferative potential in culture of cells from p53deficient mice. Oncogene 8:3313-3322.

Yao GL, Kato H, Shimada S, Kiyama H (1995a) Differential expression of JAK family genes in rat hypoglossal motoneurons after nerve injury. Soc Neurosci Abstr 21:426.5.

Yao GL, Kiyama H (1995b) Dexamethasone enhances level of GAP-43 mRNA after nerve injury and facilitates re-projection of the hypoglossal nerve. Mol Brain Res 32:308-312.

Yoneda T, Inagaki Y, Hayashi Y, Nomura T, Takagi H (1992) Differential regulation of manganese and copper/zinc superoxide dismutases by the facial nerve transection. Brain Res 582:342-345.

Zauberman A, Lupo A, Oren M (1995) Identification of p53 target genes through immune selection of genomic DNA: the cyclin G gene contains two distinct p53 binding sites. Oncogene 10:2361-2366. 